УДК $1: 32.019 .5$

DOI: $10.32837 /$ apfs.v0i24.885

\begin{abstract}
Александр Михайлович Ерёменко
доктор философских наук, профессор, и. о. заведующего кафедры философии Национальный университет «Одесская юридическая академия», г. Одесса, Украина alyeremenko@gmail.com
\end{abstract}

Денис Викторович Яковлев

доктор политических наук, профессор, декан факультета психологии, политологии и социологии Национальный университет «Одесская юридическая академия», г. Одесса, Украина yakovlevdenys@gmail.com

\title{
«МЫ ДИАЛЕКТИКУ УЧИЛИ НЕ ПО ГЕГЕЛЮ». ФИЛОСОФИЯ В ЗЕРКАЛЕ ПОЛИТИЧЕСКОЙ ПРОПАГАНДЫ: ПОПЫТКА АНТРОПОЛОГИЧЕСКОГО ПОДХОДА
}

\begin{abstract}
Аннотация. Целью исследования является демонстрация глубокой взаимосвязи философского и политического дискурсов через призму политической антропологии. Авторы исходят из анализа различия понимания противоречия диалектической и формальной логикой. Герменевтика гегелевских текстов осуществляется в контексте культурологического подхода с привлечением методологического инструментария политической антропологии. Авторы показывают, что закон исключённого третьего не отрицается в гегелевском учении о противоречии. Стремясь осознать целостность познаваемого объекта как синтетического единства противоречивых характеристик, Гегель применяет диалектическую конъюнкцию, которая не исключает, а снимает формальнологическую дизъюнкцию Аристотеля. В политическом, a особенно в пропагандистском дискурсе, как правило, осуществляется профанация философских учений, неизбежно приводящая к их искажению. Для деконструкции указанной профанации необходимо подвергать анализу мировоззренческие основания сознания субъектов современной политической и пропагандистской борьбы.
\end{abstract}

Ключевые слова: Гегель, диалектика, противоречие, Аристотель, «или - или», «и и», пропаганда, политическая антропология.

\section{1. ВВЕДЕНИЕ}

Борьба за власть в современном мире имеет множество измерений, индивидуальные и коллективные политические акторы для достижения поставленных целей задействуют все имеющиеся у них ресурсы. Безусловно, как убедительно показывает политическая антропология, некоторые ресурсы практически без изменений перекочевали в эпоху модерна из времен традиционных обществ, иные, хотя и являются сравнительно новыми, однако их источник - это также социальные и политические отношения если и не в архаических, то в доиндустриальных обществах. Среди них следует назвать экономическое (прежде всего - финансовое) давление, использование прямой военной силы и/или угрозы применения насилия, духовные факторы (культура и язык, религия и история), манипуляции которыми позволяют апеллировать к сакральному в обществе и власти.

Нельзя недооценивать и роль рациональной аргументации в политике. Она позволяет не только выстраивать внешне- и внутриполитические стратегии власти, но и давать оценку действиям политических акторов, используя научную методологию. Один из источников рационализма в политике - эпоха античности (не зря Перикла называли не только «первым гражданином», но и последовательным сторонником Анаксагора). 
Одним из наиболее важных политических ресурсов, который активно используется в борьбе за власть (и вообще, для анализа и конструирования властеотношений) является дискурс. Благодаря антропологической критике дискурсивных практик можно выделить два подхода к пониманию политического дискурса. Это одновременно и эффективный инструмент политики, благодаря которому обществу навязывается воля правящего класса, и само пространство политической борьбы. Дискурс формирует и репрезентирует общественное мнение, массовые представления, стереотипы, убеждения и предубеждения. Антропологическое измерение политики позволяет представить пространство борьбы за власть как сеть различных дискурсов, видений прошлого, настоящего и будущего человека, власти и общества. Ведь дискурс всегда наделяет определенным значением те политические практики, которые складываются на уровне отдельного политика или социальной группы. Дискурс отражает и одновременно ограничивает социальную, эпистемологическую и риторическую практику группы.

С точки зрения политической антропологии в дискурсе также присутствует определенный дуализм, обусловленный наличием как индивидуального начала, так и коллективного. Причем акцент делается именно на индивидуальном: ведь и политику долгое время рассматривали как сферу борьбы больших социальных групп - классов, недооценивая роль личностного фактора. Вместе с тем, исследования политического дискурса остро нуждаются сегодня в использовании методологического инструментария антропологии: концептуализации индивидуального участия в коллективном процессе борьбы за власть, определении роли выбора личности в конструировании политических отношений. На этом дуализм не заканчивается. С одной стороны, под дискурсом можно понимать совокупность «...важных агентов политической коммуникационной сети, выступающих в роли ретрансляторов, кодов и континууме смыслов, ценностей, идей, образов, мыслей, интерпретаций и других ментальных и виртуальных образований» (Rusakova, 2006, с. 30).С другой - дискурсы могут рассматриваться как один из самых эффективных властных ресурсов, спомощью которого государственные и политические институты осуществляют свою самопрезентацию и легитимацию, конструируют и продвигают те или иные образы реальности, позиционируют политических субъектов в специфической сфере взаимодействия - символьном пространстве.

Политический дискурс, в отличие от множества других дискурсов, является наиболее массовым. Именно политический дискурс наиболее полно транслируется современными медиа, а политические акторы активно используют коммуникативные технологии, которые позволяют наиболее эффективно бороться за власть. С одной стороны, может создаться впечатление, что политический дискурс доминирует над другими или вообще является автономной сферой; однако, с другой стороны, именно в политическом дискурсе наиболее заметными являются заимствования из других дискурсов, апелляция к дискурсам иных социальных групп, их цитирование и интерпретация.

Целью данного исследования является демонстрация глубокой взаимосвязи философского и политического дискурсов через призму политической антропологии. Ведь одно из главных достижений современной политической антропологии заключается именно в смещении иследовательской оптики от объекта (которым в данном случае выступает политический дискурс) к процессу взаимодействия и взаимного влияния между философским и политологическим дискурсами, с одной стороны и политическим и пропагандистским дискурсами, с другой. В центре нашего внимания - фигура эксперта (интеллектуала), который обращается к философскому дискурсу для контруирования пропагандистского дискурса. 
На конкретном примере нам хотелось бы показать, как традиционные философские объяснения и отсылки к авторитетам сегодня используются с целью создания пропагандистских клише, манипуляции общественным мнением. А это, как явствует из антропологического подхода, и есть та реальность, которую мы исследуем и одновременно создаем.

Это также означает попытку через индивидуальные высказывания отдельных политиков и экспертов, которые работают на грани политического и философского дискурсов проследить общие тенденции развития дискурсов, их взаимное влияние и проникновение, общие проблемы и пути их преодоления.

Ведь, несмотря на то, что философский и политический дискурс преследуют различные цели (в наиболее широком смысле - «власть» и «истина»), еще со времен античности философами предпринимаются смелые попытки «похода во власть», стремление концептуально повлиять на политический дискурс. Политики же, в силу своей специфики, часто прямо либо опосредованно определяют «повестку дня» для других дискурсов, в том числе - для философского дискурса. Не только в тоталитарных или посттоталитарных государствах, но и в условиях демократических политических режимов существует множество примеров того, как пропагандистский политический дискурс упрощает и искажает собственно философский дискурс.

\section{2. РЕЗУЛЬТАТЫ ИССЛЕДОВАНИЯ}

«Человек политический», который находится в центре антропологической парадигмы, ищет ответы на вызовы современности в философской классике, работах Аристотеля, Макиавелли, Гоббса, Канта, Гегеля еtс. В свою очередь работа пропагандиста (которого также можна отнести к «НоomoPoliticus») предполагает определенные манипуляции общественным мнением. В чем же причина того, что пропагандисты обращаются к философскому наследию, цитируют классиков? Только ли дань моде или традиции ими движет?

Политика, как пространство презентации и столкновения индивидуальных интересов (в своей представительской парадигме) требует повышенного внимания и постоянного обращения к другим дискурсам - в том числе философскому и научному. Многие политические деятели и в Украине и за рубежом позиционируют себя как интеллектуалов. Наоборот, многие интеллектуалы поддаются искушению труда во имя «общего блага» и начинают карьеру политика или чиновника. При этом они привносят в политический дискурс элементы иных, близких им самим, дискурсивных практик. Все это актуализирует исследования взаимного влияния политического дискурса и дискурса интеллектуалов. Это обширная тема, которая требует обращения к истории формирования определенной модели отношений государства и общества, феномена «русской интеллигенции», «советской интеллигенции», современных экспертных сообществ (экономистов, политологов, социологов), взаимодействия политического, политологического и философского дискурсов.

После распада Советского Союза политический дискурс изменился до неузнаваемости: практически полностью исчезли навязчивые упоминания марксизмаленинизма и советский политический «новояз», а «перестройка», «гласность» и «новое мышление» М. Горбачева открыли шлюзы для заимствований (часто некритических, а иногда просто бессмысленных) из западного дискурса. В полной мере это относится и к философскому дискурсу. Вместе с тем, в постсоветском политическом дискурсе сохранилась другая традиция - не называть вещи своими именами, конструировать «двойное «смысловое» дно». Успешно воспроизводилась свойственная советскому 
политическому языку двусмысленность, когда говорится одно, а подразумевается совершенно другое. До сих пор политический дискурс в Украине не смог преодолеть советской традиции: «[до недавнего времени]...война у нас называется «антитеррористической операцией», политический кризис - «децентрализацией», а капитуляция - «особым статусом» [10].

В конце концов, пора уже осознать отличия политического дискурса в Украине как от советского так и условно говоря, от западного политического дискурса, который формировался в определенных исторических условиях и прошел разные этапы.

Можно привести ряд примеров публикаций действующих политиков, в которых они позиционируют себя не только как чиновников, но и как интеллектуалов, претендующих не просто на формулирование неких идеологических ориентиров, но на философское и историософское обоснование этих ориентиров.

Состояние современного политического дискурса в Украине О. Покальчук в статье «Инакодействие» [10] называет «авторитарным плюрализмом». С этим можно согласиться. При наличии плюрализма социальных групп и политических акторов (позиций) в современном украинском обществе, каждый из них претендует на (в абсолютно советском духе) монополизацию дискурсивного пространства, представление своей позиции в качестве безальтернативной, «единственно верной» и т.д. Именно в преодолении «авторитарного плюрализма» видится сегодня основная роль философского и политологического дискурсов. Но не только. В современных условиях аннексии части украинских территорий, необходимости одновременного решения двух задач - демократизации и повышения обороноспособности, крайне важно не допустить следующего. Во-первых, окончательного скатывания к популизму:

Сходятся мыслители на двух направлениях, определяющих суть популизма - на различных хождениях в народ (и сюда, к оскорблению многих, можно вполне отнести наше волонтерство) и политической демагогии, то есть авторизованной медийной лжи ... Популизм всегда оппозиционный и борется за возвращение власти народу, у которого ее вырвали из рук жадные олигархи у власти. Но борется так, чтобы ненароком не отдать, потому что самому надо. Это в науке называется «институциональный парадокс». Противопоставление «простого народа» и «злодеев» обязательно. Простой народ - это всегда те, к кому популист обращается. [11].

Во-вторых, сжатия политического дискурса, сведения всего многообразия политических дискурсивных практик к критике всего и вся, вместо вскрытия глубинных социальных причин происходящего. По мнению Ивана Дзюбы [13] «...наивным или даже примитивным кажется взгляд, который все бедs объясняет некомпетентностью (варианты - недобросовестностью, безответственностью, коррумпированностью и т. д.) министров. Но министры меняются, а бедs остаются. На смену некомпетентным (коррумпированным и т.д.) приходят те, кто упрекал их в некомпетентности (коррумпированности и т.д.), а затем и их обвиняют по полному списку тех же грехов. И этой карусели нет конца» [13].

В-третьих, на данном этапе важно не допустить использования и массового тиражирования в политическом дискурсе извращенно интерпретированных в пропагандистских целях понятий и смыслов философского и политологического дискурсов. Ведь такое толкование подрывает доверие граждан к возможностям философского и политологического дискурсов не только критически осмыслить неудачи демократических преобразований, но и предложить программу необходимых реформ в Украине.

На отдельные характеристики украинского политического дискурса, которые становятся одной из причин провала многих реформ, обращает внимание Борис Ложкин. Бывший глава Администрации Президента Украины (2014 - 2016 гг.) считает, 
что: «Люди, впервые сталкивающиеся с украинской политикой, жалуются на то, что в Украине никто не выполняет договоренностей. Мне тоже регулярно приходится сталкиваться с необязательностью партнеров по переговорам...Приходится выстраивать комбинации с запасом, учитывая, что многие «да» (какие именно неизвестно) - это на самом деле «нет» [16].

В целом ряде выступлений и статей, которые составляют часть политического дискурса можно найти прямые отсылки к философии. Например, одной из топ-тем в политическом дискурсе является проблема нового общественного договора и необходимость разработки новой конституции на этой основе. М. Ставнийчук [14] считает одной из основных задач Конституции «...создание образовательной системы обнаружения и развития талантов человека ... формирование, поддержка, пропаганда и укрепление идеологии государства на основе общечеловеческих ценностей через развитие философии (курсив наш А. Е., Д. Я.), культуры, образования и гражданских общественных медиа».

Не только конституционный процесс, но и весь комплекс политических отношений во многом зависит от позиции отечественной интеллигенции. По мнению А. Ермолаева [8]: «В Украине много интеллигентов, но так и не состоялась национальная интеллигенция. Грызня, политиканство, нарциссизм, мелкопоместныйэгоизм и все та же «моя хата с краю». Интернет-толпа блогосферы на самом деле оказалась сильнее и влиятельнее наиболее продвинутого и образованного авторитета - ученый это, преподаватель, врач или общественный активист».

В. Горбулин [7] отмечает, что в условиях «гибридной войны» очень важно создание «...своеобразного «научного хаба», определенной точки приложения усилий и знаний для объединения усилий ученых, представителей госструктур и органов сектора безопасности и обороны, гражданского общества...» с целью предоставить военнополитическому руководству страны стратегии выхода из кризиса.

Именно в такой ситуации как никогда необходим поиск ответов на политические вызовы в плоскости философского и политологического дискурсов для создания концептуальных рамок стратегии выхода Украины из точки бифуркации.

Важной составляющей такого процесса на данном этапе должна стать кропотливая работа украинских интеллектуалов по развенчиванию мифов российского пропагандистского дискурса. При этом следует согласиться с И. Дзюбой в том, что «Бороться с ложью «контр-ложью» («альтернативной» ложью) бесполезно. Единственная альтернатива лжи - достоверная информация. К сожалению, именно ее мы часто не видим и не слышим... А есть ли у нас адекватное представление о социальном составе сторонников «сепаратизма», их идеологии и аргументации? Не только же бандиты и алкоголики там и не только российским оружием они пользуются. И полемика с ними должна вестись не только оружием. Для этого надо лучше знать их и их мотивацию. Тогда и можно будет на лживую пропаганду отвечать словом правды.Пока это не всегда нам удается» [13].

Одним из примеров процесса формирования пропагандистского дискурса с использованием умышленно искаженных заимствований и объяснительных схем из философского дискурса является утверждение о неизбежности лицемерия в парадигме западной цивилизации [15]. На этом, по нашему мнению, узловом для формирования пропагандисткого дискурса, положении следует остановиться особо. Суть современной пропаганды как коммуникативной технологии (наряду с политической рекламой,PR и «резонансными» технологиями) как раз и заключается в том, чтобы конструировать политическую реальность с помощью навязывания собственной «правды» путем манипуляций. Пропагандист должен провести линию разделения между «мы» и «они» в политическом дискурсе на основе утверждений: «правда за нами», а «они 
обманывают», «им нельзя верить». Так, один из представителей российского политического истеблишмента, в полном соответствии с установками пропагандистского дискурса, считает, что лицемерие в парадигме западной цивилизации неизбежно по двум причинам.

Мы начнем со второй причины, поскольку в дальнейшем сосредоточимся на первой. Вторая причина заключается в том, что притворство является важнейшей технологией биологического выживания. То есть здесь внимание фокусируется на важности притворства, понимаемого в широком смысле слова, в социальноисторическом контексте. Трансформированное из биологической сферы в социальную и усовершенствованное в разнообразных формах притворство оказывается важнейшим средством исторического выживания и исторического успеха любой социальной общности. Против этого трудно что-либо возразить, по крайней мере, на эмпирическом уровне. Поэтому данную причину лицемерия мы вынесем за скобки и сосредоточимся на анализе первой причины, которая формулируется таким образом:

Во-первых, сама структура речи, по крайней мере, связной, «разумной» речи, слишком линейна, слишком формальна, чтобы полноценно отражать так называемую реальность. Гегель справедливо утверждал, что непротиворечивое высказывание не может быть истинным» [курсив наш - А. Е., Д. Я]. [15].

У читателя, знакомого с системой Г. В. Ф. Гегеля, последняя фраза приведенной цитаты, несомненно, вызовет особый интерес. Ведь в данной интерпретации получается, будто немецкий классик считает, что непротиворечивое высказывание $\underline{\mu e}$ может быть истинным. То есть, всякое истинное высказывание должно быть противоречивым. Несомненно, диалектическая логика в отличие от формальной предполагает, что истинное высказывание может содержать в себе противоречие, формироваться не по принципу «или/или», а по принципу «и/и», включать в себя несовместимые, противоречивые элементы. Но исчерпывается ли этой особенностью диалектического мышления суть диалектики?

В «Науке логики» учение о противоречии содержится в разделе «Сущность», а именно в разделе «Чистые рефлексивные определения сущности». Скорее всего, в данной интерпретации гегелевской диалектики, в целях усиления пропагандисткого дискурса используется следующее место из «Малой логики»:

«И в самом деле нигде: ни на небе, ни на земле, ни в духовном мире, ни в мире природы - нет того абстрактного «или - или», которое утверждается рассудком. Всё где-либо существующее есть некое конкретное и, следовательно, некое в самом себе различное и противоположное. Конечность вещей и состоит в том, что их непосредственное наличное бытие не соответствует тому, что они суть в себе [...]. Противоречие - вот, что на деле движет миром, и смешно говорить, что противоречие нельзя мыслить. Правильно в этом утверждении лишь то, что противоречием дело не может закончиться и что оно (противоречие) снимает себя само через себя». [6, с. 279280].

Сходную мысль Г. Гегель высказывает в «Большой логике», а именно, в том месте, где он показывает, что при поверхностном понимании, формулировка закона тождества $-\mathrm{A}=\mathrm{A}$ оказывается пустой тавтологией. Высказывание такого тождества «содержит лишь формальную, абстрактную, неполную истину» [5, с.34]. По мнению Гегеля, односторонняя определённость лишена истинности [5, с. 34]. И далее еще одно пояснение: «Но из этого правильного суждения непосредственно вытекает, что истина достигает полноты лишь в единстве тождества с разностью и тем самым состоит только в этом единстве» [5, с. 34-35]. 
Учитывая большую ясность и выразительность фрагмента из «Малой логики», мы будем опираться, главным образом, на этот фрагмент, но не оставим без внимания и дискурс «Большой логики».

Мы начнем свою интерпретацию Гегеля с фокусирования внимания на мысли о том, что нигде в мире «...нет того абстрактного «или - или» которое утверждается рассудком» [6, с. 279]. Чем не нравится Г. Гегелю «или - или» и почему оно абстрактное? На первый взгляд может показаться, что Гегель здесь отрицает закон исключенного третьего. Напомним, что Аристотель (Aristotel, 1978) считал этот закон законом не только логического мышления, но и бытия. В случае противоречия истинным будет либо утверждение, либо отрицание: «В самом деле, если о чём-то правильно сказать, что оно есть не белое, то правильно также сказать, что оно не есть белое. Ибо нельзя в одно и то же время быть белым и быть не белым или быть не белым деревом и быть белым деревом; так что если утверждение не присуще, то будет присуще отрицание» [3, с. 199]. По мнению Аристотеля, это наиболее достоверное положение при познании: «Но так как невозможно, чтобы противоречащее одно другому было вместе истинным в отношении одного и того же, то очевидно, что и противоположности не могут быть вместе присущи одному и тому же» [2, с. 141]. Логическая и гносеологическая достоверность являются отражением онтологического положения дел. Подтверждением онтологической природы закона исключённого третьего является существование субъекта высказывания как условия истинности или ложности высказываний о нём: «... например, относительно того, что о чём бы то ни было истинно или утверждение, или отрицание, нужно заранее знать, что оно есть» [1, c. 257].

Думается, что каждый человек не только исходя из логических рассуждений, но и на основании своей повседневной практики может убедиться в правильности закона исключенного третьего. Трудно отрицать, что мы или смотрим футбольный матч, или не смотрим, или сдаём экзамен, или не сдаём, - и тому подобное во всех прочих случаях. Аристотель весьма остроумно высмеивает человека, который на словах отрицает закон исключённого третьего: «Далее, ошибается ли тот, кто считает, что дело таким-то образом либо обстоит, либо не обстоит, и говорит ли правду тот, кто принимает и то и другое вместе? Если этот последний говорит правду, то какой смысл имеет утверждение, что природа вещей именно такова? [...] Действительно, почему такой человек идёт в Мегару, а не остаётся дома, воображая, что туда идёт? И почему он прямо на рассвете не бросается в колодезь или в пропасть, если окажется рядом с ними, а совершенно очевидно проявляет осторожность, вовсе не полагая, таким образом, что попасть туда одинаково нехорошо и хорошо?» [2, с. 132-133].

Но действительно ли Г. Гегель отрицает закон исключенного третьего? И, учитывая многомерную тонкость гегелевского мышления, уточним: действительно ли Гегель полностью отрицает этот закон, действительно ли он считает закон исключенного третьего однозначно ложным ?

Чтобы прояснить суть гегелевского способа мышления, обратимся к его блестящему эссе «Кто мыслит абстрактно». В нем Г. Гегель показывает, что вопреки мнению обывателя о том, что абстрактно мыслит, например, философ или учёный, зачастую абстрактно мыслит сам обыватель. Причём, это «плохая» абстракция в отличие от «хорошей», которой, несомненно, оперируют философ и ученый.

Г. Гегель описывает сцену диалога (препирательства) между рыночной торговкой и покупательницей, по всей видимости, списанную с натуры: ««Эй, старуха, ты торгуешь тухлыми яйцами!» - говорит покупательница торговке. - Что? - кричит та. Мои яйца тухлые?! Сама ты тухлая! Ты мне смеешь говорить такое про мой товар! Ты! Да не твоего ли отца вши в канаве заели, не твоя ли мать с французами крутила, не твоя

(C) А. М. Еременко, Д. В. Яковлев, 2019 
ли бабка сдохла в богадельне! Ишь, целую простыню на платок извела! Знаем, небось, откуда все эти тряпки да шляпки! Если бы не офицеры, не щеголять тебе в нарядах!» $[4$, c.393].

В чем именно абстрактность мышления торговки в данном эпизоде? И в чем ложность этой абстракции? Нередко, при поверхностном понимании, полагают, что ложность в тривиальном несоответствии действительному положению дел, обусловленному обидой торговки и её неосведомленностью о покупательнице. То есть, ложность, попросту говоря, в том, что задетая критикой своего товара торговка элементарно клевещет на покупательницу. Такая интерпретация упрощает суть гегелевской мысли. Усложним ситуацию. Может ли такое быть, что все то, что говорит торговка о покупательнице, - правда? То есть, что отец покупательницы действительно умер в канаве, что её мать «крутила» с оккупантами, что сама покупательница гуляет с офицерами, которые дарят ей наряды и т. П. Почему бы нет? Рыночные торговки обычно хорошо осведомлены. Вполне может быть что вся, в гневе выплёскиваемая информация о покупательнице, чистая правда.

Но даже в этом случае, мышлению торговки присуща «плохая», «ложная» абстрактность. То есть, даже если каждое слово торговки соответствует действительности, она все равно заблуждается в плане ложной абстрактности.

В чем же заключается эта ложность? Для торговки дама, посмевшая подвергнуть критике её товар, является, так сказать, воплощением вселенского зла: торговка видит в ней только негативные черты. Может такое быть, что дама не разбирается в куриных яйцах, но разбирается в шляпках? Что она некрасива с точки зрения торговки, но красива с точки зрения офицеров? Что она добра и мила для членов своей семьи? Вполне возможно, что так и есть. Но это означает, что дама $\underline{u}$ умна, $\underline{u}$ глупа, $\underline{u}$ красива, $\underline{u}$ некрасива, $\underline{u}$ добра, $\underline{u}$ зла, - и т. д. То есть, в отношении дамы как целостного человека, необходима не дизъюнкция, а конъюнкция.

Ложность плохой абстракиии заключается в её односторонности, однобокости, одномерности. Используя «хорошую» абстракцию, мы должны констатировать, что дама $\underline{u}$ хороша, $\underline{u}$ плоха. И такова не только дама, но всякое сущее, которое является многосторонним и многомерным. Напоминаем гегелевское: «Всё где-либо существующее, есть некое конкретное и, следовательно, некое в самом себе различное и противоположное». Выше мы приписали даме не просто различные противоположные характеристики. И мы сделали это в отношении одного и того же человека.

Здесь уместно обратиться к «Большой логике: «Абстрактное тождество с собой ещё не есть жизненность; оттого, что положительное есть в себе самом отрицательность, оно выходит вовне себя и начинает изменяться. Таким образом, нечто жизненно только если оно содержит в себе противоречие и есть именно та сила, которая в состоянии вмещать в себе это противоречие и выдерживать его. Если же нечто существующее не в состоянии в своём положительном определении в то же время перейти в своё отрицательное [определение] и удержать одно в другом, если оно не способно иметь в самом себе противоречие, то оно не живое единство, не основание, а погибает в противоречии. Спекулятивное мышление состоит лишь в том, что мышление удерживает противоречие и в нем само себя...» [5, с. 66].

На первый взгляд, гегелевская диалектическая конъюнкция полностью «побивает» аристотелевскую формально-логическую дизъюнкцию закона исключенного третьего. Но не будем торопливы в однозначных оценках. Такое впечатление, что Аристотель предвидел гегелевскую постановку вопроса и заранее возразил великому диалектику. Стагирит вносит определённые уточнения в формулировку закона исключённого третьего: «А именно: невозможно, чтобы одно и 
то же в одно и то же время было и не было присуще одному и тому же в одном и том же отношении (и всё другое, что мы могли бы ещё уточнить, пусть будет уточнено во избежание словесных затруднений) - это, конечно, самое достоверное из всех начал...» [2, с. 125]. И снова Стагирит подчёркивает, что логическая невозможность неразрывна с онтологической: «Итак, если невозможно одно и то же правильно утверждать и отрицать в одно и то же время, то невозможно также, чтобы противоположности были в одно и то же время присущи одному и тому же, разве что обе присущи ему лишь в каком-то отношении, или же одна лишь в каком-то отношении, а другая безусловно» [2, c. 141].

Возникает вопрос: знал ли Гегель об этих уточнениях Аристотеля? И что бы он ответил на эти уточнения? Гегель, несомненно, знал. Согласился ли бы он с уточнениями Аристотеля? Здесь мы вынуждены взять на себя смелость помыслить «за» немецкого классика. Полагаем, что частично согласился бы. Почему «частично»? Вопервых, Гегель мог бы подчеркнуть важность целостности всякого сущего, к которому применяется закон исключенного третьего. Верно, что данный человек в прошлом году был необразованным, а в этом году стал образованным. Но каким он является как целостный субъект своего жизненного процесса? Каким он является, если на него посмотреть не с точки зрения прошлого и нынешнего года, а в целостном процессе его жизни и духовного развития? (В дискурсе Гегеля не случайно возникает тема «жизненности», «живого единства»). Он является и необразованным, и образованным. Верно, что человек добр к друзьям и зол к врагам. Но каким он является как целостная личность? Каким он является как синтетическое единство разнообразных сторон его Я? Он является и добрылм, $u$ злылм.

Во - вторых, Г. Гегель мог бы указать на некоторые сложные, тонкие, неоднозначные ситуации, в которых формальная дизъюнкция закона исключенного третьего перестаёт работать. Посмотрим на хрестоматийно известное стихотворение Катулла, описывающее драматичную кульминацию его романа с Клодией - Лесбией:

«И ненавижу её и люблю.

«Почему же?» - ты спросишь.

Сам я не знаю,

Но так чувствую я - и томлюсь.» [9, с.138].

Катулл одновременно и любит, и ненавидит ветреную красотку. Можно возразить, что он любит и ненавидит её в разных отношениях. Вообще-то говоря, он любит Клодию, а ненавидит её за то, что она ему изменяет. Но такое понимание будет неоправданной рационализацией любви. Любовь, а в определенном смысле и ненависть, является целостным чувством, она захватывает любящего целиком. Если мы говорим: «А любит Б за такие-то свойства, а за такие-то ненавидит или презирает», - то мы осуществляем недопустимое «дробление» и недопустимую рационализацию любви. Если мы по- настоящему любим, то мы любим человека в его целостности, мы приемлем его таким, какой он есть, со всеми его недостатками. Во-вторых, если мы любим его «за» что-то, то это вообще не любовь. Те или иные свойства человека могут быть важны в самом начале возникновения нашего чувства, они могут пробудить нашу любовь, но после того, как чувство пробуждается, оно захватывает нас целиком, и первоначально значимые свойства любимого уже не столь значимы, поскольку интегрируются в его целостный воображаемый образ. Если мы можем объяснить, за что именно мы любим этого человека, значит это либо ещё не любовь, либо уже не любовь, либо вообще не любовь.

Итак, создается впечатление, что Гегель в союзе с Катуллом вновь «побивают» строгую дизъюнкцию Аристотеля. Но и в этом случае не будем торопиться. Согласимся, что случай Катулла довольно непрост и неоднозначен. Катулл - поэт, то 
есть, человек тонкой и сложной душевной организации. В подобной ситуации большинство древнеримских обывателей (и не только древнеримских) просто наказали бы изменщицу. Катулл же вместо этого сочиняет шедевр любовной лирики.

Нужно сказать, что иногда пропагандисты также рассуждают достаточно тонко и глубоко - ведь им необходимо быть убедительными, чтобы манипулировать нашим выбором. Более того, пропагандисткий дискурс невозможен без того самого понимания необходимости разграничения сфер применяемости «или - или», и «и - и», на котором мы настаиваем: «То, что кажется логичным, всегда более или менее ложно. Язык - это двумерное пространство, все выразительные средства, всё «богатство и многообразие» которого сводится на самом деле к бесчисленным повторам в разных масштабах и на разные темы простейшей смыслообразующей пары «да/нет». Этот включатель/выключатель любого слова и любых словосочетаний от просьбы передать горчицу до «Братьев Карамазовых» и теории суперструн - щёлкает тысячи раз в день в миллиардах голов. Но сколько бы он ни щёлкал, он не может впихнуть негабаритный многомерный мир в плоское человеческое мышление. Повсеместное и, можно сказать, необузданное применение двоичных кодов (да/нет, 0/1, +/-, бог/человек, ангел/демон, республиканец/демократ, правда/ложь и т. д. и т.п.) хорошо работает. Однако хорошо работать не значит быть истиной. Поэтому даже во время редких приступов острой правдивости люди говорят не совсем то, что есть на самом деле - «мысль, изреченная есть ложь».» [15].

Получается, что современные творцы пропагандисткого дискурса вполне адекватно понимают суть гегелевского учения: они прекрасно видят недостаточность бинарных оппозиций для описания «негабаритного» многомерного мира. На это мы возразим следующее. Во-первых, несмотря на поправки и уточнения, так сказать, «узкая» суть наших претензий остаётся неизменной. Гегель нигде не говорит, что непротиворечивое высказывание не может быть истинным.

Второе. Возвращаемся к вопросу об уместности формально-логической дизъюнкции. Напомним, что во множестве случаев «или - или» прекрасно работает, и привлечение «и - и» в этих случаях окажется «дурным философствованием». В некоторых ситуациях постановка вопроса о том, что же именно является истиной, так сказать истиной «в высшем», «в метафизическом» смысле окажется просто интеллектуальным пижонством. Если мы просим передать нам горчицу, то вся «истина» нашей просьбы заключается в том, чтобы нам передали горчицу - и точка. Для этого «выключатель» да/нет вполне достаточен.

Третье, в данном случае главное. Практика политического действия (включая принятие решений) предполагает использование «или - или» либо «и - и»? На наш взгляд скорее «или - или», чем «и - и». Возможно, именно антропологический подход позволяет увидеть, что политическое действие должно быть ближе к передаче горчицы, чем к трактовке «Братьев Карамазовых». Как же так? Социально-политическая, международная, социокультурная реальность есть настолько сложная, многомерная, многоуровневая система, требующая учета огромного количества факторов, принятия непростых, «тонких», изощрённых решений, что по сравнению со сложностью этой системы и «Братья Карамазовы» померкнут. Какое «или - или», какая горчица?

Верно, что система современной международной политики чрезвычайно сложна и многомерна. Но вся эта сложность, требующая многообразного применения диалектических конъюнкций, должна остаться на уровне анализа, понимания, осмысления. Когда мы переходим в плоскость практического действия, то есть реализации нашего выбора одной из альтернатив, то «и -и» должно уступить место «или - или». В этой сфере отсутствие определенности будет губительно, особенно для претерпевающей стороны. 
По нашему мнению, гегелевская диалектическая конъюнкция вовсе не отрицает строгую дизъюнкцию закона исключенного третьего, а вбирает её в себя. Это именно диалектическое отрицание, то есть, снятие. Во многих - подавляющем большинстве повседневных (и политических) ситуациях аристотелевское «или - или» работает безотказно. То, что мы или смотрим футбольный матч, или не смотрим, или сдаём экзамен, или не сдаём, или покупаем товар, или не покупаем, - и т.д., бесспорно. Подобные ситуации не требуют никакого «и - и». В политике вполне возможен (а в переходные периоды даже крайне желателен) однозначный выбор политического класса в пользу демократии, а не авторитаризма. Если такой выбор сделан не будет, то получим «гибридный» политический режим. Также рационально выбрать одну из форм правления: или парламентскую или президентскую, их совмещение позволяет говорить о «гибридной» модели управления. Наконец, можно сделать выбор одной из альтернатив относительно избирательной системы, избрав, к примеру, пропорциональную или мажоритарную модель, и т.д.

Однако наш случай иной. Интеллектуальную суть рассмотренной ситуации можно пояснить с помощью следующей аналогии. Теория относительности А. Эйнштейна не опровергает механику И. Ньютона, но вбирает её в себя. Формулы Ньютона остаются истинными для скоростей, достаточно далеких от скорости света. А. Эйнштейн с глубочайшим уважением относился к И. Ньютону и, насколько нам известно, не противопоставлял «в лоб» теорию относительности ньютоновской механике. Точно так же, по нашему убеждению, Г. Гегель не противопоставлял «в лоб» свою диалектическую логику силлогистике Аристотеля, но полагал, что первая вбирает в себя вторую. Он не отрицал закон исключенного третьего - он «всего лишь» показывал его ограниченность. Г. Гегель даёт понять, что если мы хотим познать тот или иной объект в его целостности, в его развитии, в его «жизненности», мы должны суметь увидеть и удержать в мышлении различные и даже противоречивые свойства этого объекта, благодаря взаимодействию которых он, собственно, и развивается; мы должны понять данный объект как диалектическое синтетическое целое, что вынудит нас выйти за пределы строгой дизъюнкции закона исключенного третьего. Bыŭти за nредель, но не отбросить. Немецкий классик с глубочайшим уважением относится к классику древнегреческому.

\section{4. ЗАКЛЮЧЕНИЕ}

Можно спорить по поводу нашей трактовки учения Г. Гегеля о противоречии, и вполне возможно, что специалисты найдут изъяны в нашей аргументации и предложат свои собственные, каждый раз «единственно верные» интерпретации гегелевского учения. Но трудно отрицать то, что Гегель нигде, ни в одном месте своих работ не говорит того, что приписывает ему пропагандистский дискурс, а именно, что «...непротиворечивое высказывание не может быть истинным» [15]. Если мы ошибаемся, то пусть нам укажут соответственное место.

Антропологический подход позволяет увидеть, как и с какой целью в «незападном» дискурсе политической пропаганды используются положения (намеренно или невольно упрощённые) классиков философской мысли, которые стали фундаментом западной политической практики. Подчеркнем, что именно политическая антропология открывает возможности для дальнейшего изучения «иных» относительно западного политического процесса институтов и практик, которые производятся сегодня в некоторых постсоветских странах. А также для изучения механизмов воспроизведения символов и смыслов советского и даже имперского периодов в дискурсе политической пропаганды.

(C) А. М. Еременко, Д. В. Яковлев, 2019 
И в связи с этим мы хотели бы обратить внимание на следующее. Когда идеологи нынешнего политического курса российского истеблишмента обосновывают решения государственной власти, они всячески подчеркивают необходимость учитывать неоднозначную историю России, непростой менталитет русского народа, богатые культурные традиции, духовные «скрепы», - и т.д., и т.п. В ход пускается тяжелая артиллерия метафизики и лёгкая кавалерия диалектики. Короче: «Поймите нас, таких тонких и сложных, хоть это и непросто». И после всех этих интеллектуальных ухищрений по отношению к Украине принимается жесткое и весьма однозначное решение «держать и не пущать». Погодите, уважаемые мастера диалектического синтеза: а вы не хотите осознать сложность, многомерность, многоаспектность украинского социума? Не хотите осмыслить неоднозначность украинского геополитического выбора, обусловленного неоднозначной историей Украины, менталитетом украинского народа и т.д., и т.п.? Не хотите понять нас? А вместо этого по отношению к Украине - «Ultima ratio regum».

Однако пора вернуться к великому диалектику. При толковании Г. Гегеля никогда не следует ставить точку, но всегда многоточие. Категория противоречия занимает существенное место в гегелевской системе, но не исключительное и - важно подчеркнуть - далеко не завершающее. Непосредственное наличное бытие конечных вещей не соответствует их сущности, что, в конечном счёте, обусловливает их гибель. Но это несоответствие с другой стороны обусловливает их существование и развитие, в каковом развитии они способны удерживать противоречие внутри себя. Противоречивость влечет вещи к их основанию, а оно, в свою очередь, переходит в существование.

«Вещь, субъект, понятие есть именно само это отрицательное единство: оно нечто в самом себе противоречивое, но точно так же и разрешенное противоречие; оно основание, которое содержит свои определения и есть их носитель. [...]. Поэтому конечные вещи в своём безразличном многообразии вообще таковы, что они противоречивы в себе самих, надломлень внутри себя и возвращаются в своё основание».[5, с. 69].

Итак, чтобы правильно понять способ мышления представителей современного пропагандисткого дискурса, следует углубиться в основание их мировоззрения с позиций философского и политологического дискурсов. При этом нелишне напомнить афоризм великого немецкого классика: «Всё, что есть в мире испорченного, испорчено на хороших основаниях» [6, с. 286].

\section{СПИСОК ИСПОЛЬЗОВАННЫХ ИСТОЧНИКОВ}

1. Аристотель. Вторая аналитика / Аристотель. Сочинения в четырёх томах. Т. 2. - М., «Мысль», 1978. - 687 с. - С. 255-346.

2. Аристотель. Метафизика / Аристотель. Сочинения в четырёх томах. Т. 1. М., «Мысль», 1975. - 550 с.- С. 63-367.

3. Аристотель. Первая аналитика / Аристотель. Сочинения в четырёх томах. Т. 2. - М., «Мысль», 1978. - 687 с. - С. 117-254.

4. Гегель Г. В. Ф. Кто мыслит абстрактно? / Гегель Г. В. Ф. Работы разных лет. В двух томах. Т. 1. - М., «Мысль», 1972. - 668 с. - С. 387-394.

5. $\quad$ Гегель Г. В. Ф. Наука логики. В 3-х т. Т. 2. - М., «Мысль», 1971. - 248 с.

6. Гегель Г. В. Ф. Энциклопедия философских наук. Т. 1. Наука логики. М., «Мысль», 1974. - 452 с.

7. Горбулін В. «2017-й: далі буде...» [Електронний ресурс] / В. Горбулін // Дзеркало тижня. - 2016. - Випуск № 24. - 2-9 липня. - Режим доступу:

(C) А. М. Еременко, Д. В. Яковлев, 2019 
8. https://dt.ua/article/print/internal/2017-y-dali-bude-cinnisni-resursi-viyni-imiru-ukrayinskiy-format-_.html

9. Срмолаєв А. Майбутнє мінливе. Бо - змінюване [Електронний ресурс] / А. А. Єрмолаєв // Дзеркало тижня. - 2017. - Випуск № 3. - 28 січня - 3 лютого Режим доступу:https://dt.ua/article/print/internal/maybutnye-minlive-bo-zminyuvane-_.html

10. Катулл. Тибулл. Проперций. - M., Гос. изд-во художественной литературы, 1963. - 512 с.

11. Покальчук О. Інакодія [Електронний ресурс] /О. Покальчук //Дзеркало тижня. - 2015. Випуск № 43. - 13 листопада. - Режим доступу: https://dt.ua/socium/inakodiya-_.html

12. ПокальчукО. Народоблуддя [Електронний ресурс] /О. Покальчук // Дзеркало тижня. - 2016. -Випуск № 32. - 10-16 вересня. - Режим доступу: https://dt.ua/article/print/SOCIUM/narodobluddya-_.html

13. Русакова О.Ф. Политическая дискурсология: предметное поле, теоретические подходы и структурная модель / О.Ф. Русакова, Д.А. Максимов // Политические исследования. - 2006. - № 4. - С. 26-43.

14. Савенко О. Іван Дзюба: «Може, саме тепер формується політична українська нація, про яку весь час говорилося»: інтерв'ю [Електронний ресурс] /О.Савенко // Дзеркало тижня. - 2015. -Випуск №18. - 22-29 травня. - Режим доступу:https://dt.ua/personalities/ivan-dzyuba-mozhe-same-teper-formuyetsya-politichnaukrayinska-naciya-pro-yaku-ves-chas-govorilosya-_.html

15. Ставнійчук М. Дві України. Поле бою - Конституція // Дзеркало тижня. 2016. - Випуск № 23. - 23-2 липня. - Режим доступу:https://dt.ua/article/print/internal/dviukrayini-pole-boyu-konstituciya-ukrayini-sogodni-potribni-principovo-nova-konstituciyanovi-gorizonti-suspilnogo-rozvitku-i-pravovih-oriyentiriv

16. Сурков В. «Кризис лицемерия». Ihear Americasinging [Электронный peсурс] / В. Сурков // RT на русском. - 7 ноября 2017. - Режим доступа: https://russian.rt.com/world/article/446944-surkov-krizis-licemeriya

17. Четвертая республика. Что нужно знать о книге главы Администрации президента [Электронный ресурс] // Украинская правда. - 2016. - 18 марта. - Режим доступа: https:/www.pravda.com.ua/rus/articles/2016/03/18/7102565/.

\section{«МИ ДІАЛЕКТИКУ ВЧИЛИ НЕ ЗА ГЕГЕЛЕМ». ФІЛОСОФІЯ У ДЗЕРКАЛІ ПОЛІТИЧНОЇ ПРОПАГАНДИ: СПРОБА АНТРОПОЛОГІЧНОГО ПІДХОДУ}

Анотація. В статті обгрунтовується важлива роль раціональної аргументації в сучасній політиці. Метою дослідження $є$ демонстрація глибокого взаємозв'язку філософського і політологічного дискурсів через призму політичної антропології. Показано, що антропологічний підхід $є$ ефективним для дослідження механізмів відтворення символів та смислів радянського і навіть імперського періоду в дискурсі сучасної пострадянської пропаганди.

Автори виходять 3 аналізу відмінності в розумінні протиріччя діалектичною $\mathrm{i}$ формальною логікою. Герменевтика гегелівських текстів здійснюється в контексті культурологічного підходу із залученням методологічного інструментарію політичної антропології. Автори показують, що закон виключення третього не спростовується в гегелівському вченні про протиріччя. Намагаючись усвідомити цілісніть об'єкта, що пізнається, як синтетичну єдність характеристик, які взаємно суперечать, Гегель використовує діалектичну кон'юнкцію, яка не виключає, а знімає формально-логічну диз'юнкцію Аристотеля.

Автори наполягають на доцільності розрізнення сфер суспільної комунікації: в одних методологічну і практичну ефективність матиме звичайна диз'юнкція, в 
інших - діалектичний синтез різноманітних і навіть протилежних характеристик об' єкту та висловлювань про нього.

В політичному, а особливо в пропагандистському дискурсі, як правило, здійснюється профанація філософських вчень, яка неминуче призводить до їх спотворення. Прикладом такої профанації $\epsilon$ інтерпретація В. Сурковим гегелівського вчення про діалектичне протиріччя. На основі власного тлумачення вчення Г. Гегеля про протиріччя, автори здійснюють реконструкцію тексту В. Суркова. Автори підкреслюють, що для деконструкції такої профанації необхідно піддавати аналізу світоглядні засади свідомості суб’єктів політичної та пропагандистської боротьби.

Ключові слова: Гегель, діалектика, протиріччя, Аристотель, «або - або», «і - i», пропаганда, політична антропологія.

\section{"WE STUDIED DIALECTICS NOT ACCORDING TO HEGEL" THE PHILOSOPHY IN THE MIRROR OF POLITICAL PROPAGANDA: AN ATTEMPT TO THE ANTHROPOLOGICAL APPROACH}

Abstract. The article substantiates the important role of rational argument in contemporary politics. The purpose of the research is to demonstrate the deep interconnection of philosophical and political discourses through the lens of political anthropology. The anthropological approach has been shown to be effective in exploring the mechanisms of reproduction of the symbols and meanings of the Soviet and even imperial periods in the discourse of contemporary post-Soviet propaganda.

The authors proceed from the analysis of differences in understanding of contradictions by dialectical and formal logic. The hermeneutics of Hegelian texts is carried out in the context of a cultural approach, involving the methodological tools of political anthropology. The authors show that the law of exclusion of the third is not refuted in Hegel's doctrine of contradiction. In seeking to target the object of what is known as the synthetic unity of conflicting characteristics, Hegel uses a dialectical conjunction that does not exclude but removes Aristotle's formal-logical disjunction.

The authors insist on the expediency of distinguishing the spheres of public communication: in some the methodological and practical efficiency will have the usual disjunction, in the others - the dialectical synthesis of various and even opposite characteristics of the object and statements about it.

In political, and especially in propaganda, discourse, as a rule, is making a profanation of philosophical teachings, which inevitably leads to their distortion. An example of such profanity is V. Surkov's interpretation of the Hegelian doctrine of dialectical contradiction. Based on G. Hegel's own interpretation of the contradiction, the authors reconstruct V. Surkov's text. The authors emphasize that to deconstruct such profanity, it is necessary to analyze the outlook of the minds of the subjects of political and propaganda struggle.

Keywords: Hegel, dialectics, contradictions, Aristotle, "or - or", "and - and", propaganda, political anthropology. 